\title{
EXPLORING STUDENTS' PERCEPTIONS ON ACQUISITION OF TRANSVERSAL SKILLS DURING AN ONLINE SOCIAL SIMULATION
}

\author{
Agnese Dāvidsone1, Külliki Seppel², Austè Telyčènaitė3, \\ Renata Matkevičienè ${ }^{3}$, Marko Uibu'², Vineta Silkāne', \\ Anžela Jurāne-Brēmane', Õnne Allaje ${ }^{2}$ \\ ${ }^{1}$ Vidzeme University of Applied Sciences, Latvia \\ ${ }^{2}$ University of Tartu, Estonia \\ ${ }^{3}$ Vilnius University, Lithuania
}

\begin{abstract}
Due to the demands of the current job market, universities need to adapt their teaching approaches to provide students with opportunities to advance their transversal skills in order to succeed with their careers. Social simulations have been considered previously as a fruitful study method that helps to advance transversal skills; however, the research in this field is scarce. This study aims to explore the perceived affordances and limitations of social simulation as an online learning method for acquisition of transversal skills of graduate and undergraduate students from communication and media study programs. The empirical part draws on a set of qualitative data. All together 32 students in two universities participated in the testing of an original simulation scenario that was created in an Erasmus+ Strategic partnership project. The results indicate that students in both simulation exercises mostly applied their negotiation, strategic thinking and planning skills. During the second simulation, self-evaluation forms filled before and after the event helped the students to realize which transversal skills they need and want to develop further. Our results demonstrate that students felt pressured to intensively collaborate and coordinate with their group members, other groups and the teachers as during both testing sessions technical disruptions were experienced. We conclude that an online social simulation is a productive interactive learning and teaching method that helps to sensitize students towards their transversal skills and stimulate self-reflection. We also argue that in exercising a social simulation online there is an additional layer of pedagogical implications: the choice of the digital platform and the potential technical disruptions such as the loss of Internet connection or sudden malfunction of some of the platform's features may divert the flow of the simulation.
\end{abstract}

Keywords: interactive learning, online learning environments, social simulations, transversal skills, $21^{\text {st }}$ century skills. 


\section{Introduction}

Preparing students for the $21^{\text {st }}$ century challenges means preparing them for living and working in rapidly changing situations that require sophisticated comprehension and fast, flexible adaptation in order to be successful with one's career (European Commission, 2011; Milakovich \& Wise, 2019). According to the World Economic Forum (2019), creativity, problem solving, teamwork, critical thinking and emotional intelligence should be highlighted as the skills that will be increasingly demanded. Educators thus experiment with various study methods and tools that support not only the acquisition of specialist knowledge or job specific skills, but also the so-called transversal skills. Reuter, Ferreira Dias, Madaleno et al. (2020) emphasize that for advancement of transversal skills it is necessary to formulate and develop effective and efficient teaching concepts that combine both theoretical and practical elements.

Scholars agree that acquisition of transversal skills happens most efficiently when learning is an active process, with the emphasis on the learner and his/her authentic experience (Reuter et al., 2020; Krpálek, Berková, Kubišová et al., 2021). Therefore, games, social simulations, role-plays and other interactive study methods are increasingly being applied as teaching methods in higher education to support acquisition of transversal skills. Technology is often seen as means of educational enrichment and tool for productivity (Torres, Sousa \& Torres, 2018). With the current study, we aim to explore the perceived affordances and limitations of social simulation as an online learning method for acquisition of transversal skills among graduate students from Communication and Public Relations study programs at University of Tartu and Vilnius University. The study was carried out as part of an Erasmus + project where universities in Latvia, Estonia and Lithuania collaborated to explore innovative study methods for higher education.

\section{Transversal skills: definitions}

Transversal skills are defined as transferable behaviors that can be used within a wide range of contexts including different functions and activities. They can be contrasted with professional and technical skills (Direito, Pereira \& Duarte, 2014). UNESCO has defined transversal skills "as not specifically related to a particular job, task, academic discipline or area of knowledge and that can be used in a wide variety of situations and work settings" (UNESCO, 2013). Thus, transversal skills are needed for everyone's full life in today's society. In previous literature, various related terms such as soft skills, $21^{\text {st }}$ century skills, key skills, core skills, employability skills, and cross-curriculum skills have been used (Deep, Salleh \& Othman, 
2019; Goggin, Sheridan, Lárusdóttir, Guðmundsdóttir, 2019). Moreover, there is an extensive discussion around the notions of skills and competences, and no consensus among scholars on the meaning of these two has been achieved so far. To avoid confusion, in the current study we use the term transversal skills considering this as the most widely used term for the skills that are opposed to job-specific skills.

UNESCO classifies transversal skills in the following five groups:

1. Critical and innovative thinking;

2. Inter-personal skills (e. g. presentation and communication skills, organizational skills, teamwork, etc.);

3. Intra-personal skills (e. g. self-discipline, enthusiasm, perseverance, self-motivation, etc.);

4. Global citizenship (e. g. tolerance, openness, respect for diversity, intercultural understanding, etc.);

5. Media and information literacy such as the ability to locate and access information, as well as to analyse and evaluate media content (UNESCO, 2013).

The UNESCO's framework partly overlaps with the one proposed by National Research Council (2012) which draws on the analysis of earlier conceptualizations, and proposes to distinguish between three broad categories of skills:

1. Transversal skills on the Cognitive domain (critical thinking, reasoning and argumentation, innovation);

2. The Intrapersonal domain (flexibility, metacognition, openness, work ethics, initiative); and

3. The Interpersonal domain (collaboration, teamwork, leadership, conflict resolution etc.) (Education for Life and Work: Developing Transferable Knowledge and Skills in the $21^{\text {st }}$ Century, 2012).

\section{Acquisition of transversal skills through interactive study methods}

Previous studies indicate that by engaging in educational activities such as games or social simulations, students acquire various transversal skills: autonomy, cooperation, digital skills, communication (see e. g., Díaz Pareja, Cámara Estrella, Muñoz Galiano et al., 2018). The meta-analysis carried out by Reuter et al. (2020) indicate that in previous studies advancement of such transversal skills as teamwork, collaboration, emotional intelligence, performance under pressure, creativity have been analyzed. In the social and human sciences, mostly the focus is on acquisition of such transversal skills: communication, argumentation, ability to negotiate, adaptability, anticipate situations, critical thinking, leadership, and motivation. It has been found that motivation helps to achieve higher 
learning outcomes in a more flexible way (Varela-Candamio, EnriquezDiaz \& Rouco-Couzo, 2020). It seems that interactive study environments naturally promote cooperation and in some cases confrontation of ideas through which students gain deeper understanding of the study content and raise self-confidence. In a game-based learning situation, the teams compete with one another and they need various resources to solve the challenges integrated in the game scenario effectively in a restricted time (Buckley \& Doyle, 2016). In a similar vein, Kirkwood-Tucker (2004) points out that the active nature of simulations requires students to engage and adapt to circumstances within a specific context, engage flexibly, communicate, and collaborate. A social simulation encourages students to practice critical thinking skills (Cummings, Mason, Shelton \& Baur, 2015), interpersonal communication, teamwork, leadership, decision-making, task prioritizing and stress management (Vlachopoulos \& Makri, 2017), as well as to experience the feelings, questions, and concerns associated with their particular role (Gredler, 2004). Synchronous online collaboration increases social presence, which promotes learning. As noted by Torres, Sousa and Torres (2018, p. 589) "technology is of paramount importance as a tool to foster students' autonomy and collaboration, and can, most interestingly, be used to promote active learning and possibly emancipation." Video, audio or even just text chat increases engagement in learning activities (Martin \& Parker, 2014).

In literature, the term "simulation" is used to convey different meanings. What we focus on in this study is a social-process simulation that is defined as an open-ended situation that can take different directions, depending on the actions and reactions of the participants (Gredler, 2004; Thavikulwat, 2009). By engaging in a social simulation exercise, students experience the effects and consequences of one's decisions and actions, they can experiment and make mistakes thus building a better overall understanding and creating new knowledge (Cummings et al., 2015; Davidsson \& Verhagen, 2017; Hill \& Semler, 2001; Kirkwood-Tucker, 2004).

\section{The role of students' reflection in learning}

Schön (1987) describes the formation of new knowledge as a result of increasing students' self-awareness of one's repertoire of knowledge and skills through creating specific circumstances during the learning. Reflection is crucial in the Schön's (1987) model. Dewey (1910) defines reflection as a cognitive activity that is active, persistent, and includes responsibility for future consequences. According to Dewey (1910), reflection can be both retrospective and progressive. As previous studies have demonstrated (see e. g., Rarieya, 2005) reflection supports learners in making sense and meaning of their learning experience. Student reflection on 
the experience gained through a learning activity also leads to an improved self-awareness of one's skills and knowledge level. Helyer emphasizes that "developing a reflection means that an individual begins to automatically challenge and question why tasks were undertaken in a certain way rather than how they were carried out" (2015, p. 23). Reflection provides the opportunity for the students to be sensitized to the variety of skills needed to achieve a result. As demonstrated by Chang's (2019) study, through reflection students could identify the gaps in their knowledge and skills. Thus, reflection may also help to define goals to enhance particular skills in the future (Coulson \& Harvey, 2013). It is especially important for the course of acquiring transversal skills which are often also called employability skills, and valued in the job market, because reflection can help to contextualize and personalize the learning experience (Chang, 2019). Ability to reflect on one's transversal skills are pivotal to development in lifelong learning (Rushton, 2005) and is a requirement in many professions (Betts, 2004). In order to make the reflection fruitful, students need to be provided with means to reflect on their skills before and after the learning activity (Coulson \& Harvey, 2013). Written reflection should be combined with oral reflection for a more in depth self-assessment (Quinton \& Smallbone, 2010).

\section{Method}

\section{The Participants}

Graduate and undergraduate students from Vilnius University $(n=16)$ and University of Tartu $(n=16)$ participated in the social simulation and the study.

\section{Data collection}

Data collection was carried out during two social simulation sessions. The focus of the social simulation was on the scenario of pollinators and pesticides. During the social simulation, participants had the opportunity to identify with different stakeholders and show a wide range of skills. Due to the COVID-19 pandemic, the social simulation that originally was prepared for in-person was transferred to online.

Lithuania: Two methods were employed for data collection: written student self-reflections (free format) and instructors' notes. Instructors' notes were made from debriefing/reflection sessions in which the following issues were discussed: gains obtained from the participation in this simulation, skills and competencies developed during simulation, opportunities and risks using social simulation as a learning method, social simulation in the online environment. 
After this simulation, a student self-reflection form was created, which was used in the next simulation in Tartu.

Estonia: Two methods were used for data collection, first, student self-reflection forms filled in before and after the simulation exercise focusing on a list of transversal skills (UNESCO, 2013; Milakovich, \& Wise, 2019 etc.). The following transversal competencies were evaluated (on the scale from 0 to 10) before and after the simulation: critical thinking, learning to learn, problem solving, flexibility, decision making in groups, managing uncertainty, communication, persuasion skills, collaboration, presentation skills, leadership and responsibility, contextual awareness, initiative and self-direction, conflict management, productivity, negotiation skills, creativity and innovation. Second, instructors' notes were made from debriefing / reflection sessions in which the following issues were discussed: gains obtained from the participation in this simulation, skills and competencies developed during simulation, opportunities and risks using social simulation as a learning method, social simulation in the online environment.

\section{Data analysis}

Medians were calculated for transversal competencies (student self-reflection forms), while student's free self-reflections and instructor notes were recorded and transcribed. All the transcripts from reflection sessions were analysed by the two researchers using the inductive thematic analysis approach. Each transcript was approached with a preliminary readthrough, and the initial analytic codes were developed. These codes were later refined and grouped into themes and sub-themes. The initial coding was performed by the researchers independently, and later the codes were compared and discussed over several meetings. The collaborative approach was employed to resolve disagreements during the process of theme identification. Such an approach was useful to reduce the risks of potential researcher bias and subjectivity.

\section{Ethical considerations}

Students' confidentiality was respected in the study. The students agreed that an audio recording would be made during the reflection sessions, which was deleted after the transcripts were created. Method section shows how the study was conducted.

\section{Results}

In the Lithuanian simulation, first of all, the theme of becoming more sensitized towards some transversal skills was prominent: several of the students mentioned that the simulation activity helped them to understand 
where they are at mastering the skills. For example, one student mentioned that "During the simulation, I realized I wasn't such a bad negotiator". A rather similar was another students' observation about herself: "I tried negotiation skills that I believe aren't really impressive, but you need to start from somewhere, and it [the simulation] was a great chance". Another student had realized that she is a much better team player than she had thought before: "Most definitely the remarkable thing was the team work. I normally prefer working in solitude, but placing my trust in my teammates' hands turned out to be very gratifying". Another student emphasized that the simulation exercise let him think about the variety of transversal skills needed to complete the task: "Simulation was an exceptional experience - such practices open the eyes to what skills are really important when trying to innovate".

The data codes revealed that negotiation and argumentation skills were the ones most often mentioned as the skills that students had to apply during the simulation. Other skills that were mentioned were strategic thinking, working in teams, presentation skills, communication, and decision making in groups. The simulation had also been an opportunity for the students to embody roles that they said they would not have taken on in real life. Such a finding points toward the fact that such simulations in general may allow students to take on unusual roles in teams, such as revealing themselves as leaders, negotiators, and so on. In this case, experiences and competencies that students have gained from participation in and use of social media platforms help them to create their identities, communication style and choose the appropriate negotiation role according to the "persona" they had to play during the simulation.

From the intra-personal skills' set (UNESCO, 2013), management of emotions was mentioned several times. Because of the remote study process due to the COVID-19 pandemic related restrictions, students had to participate in the simulation online. It meant managing various ICT platforms, which the students were not very familiar with, and also experiencing technical disruptions. Several students admitted that they had to deal with anxiety and frustration due to these technical technological challenges, as, for example, in this excerpt: "We had technical disruptions, one of our members could not join normally, so there were difficulties in communicating with the other groups and lots of confusion". Several students also realized that their ICT skills were insufficient.

In the Estonian simulation, the students were asked to fill in a self-evaluation form before the simulation, where they needed to rate their transversal skills on the scale from 0 to 10 , as well as to choose three from the list that they felt needed to be developed the most. The median evaluations of different transversal skills did not differentiate very much, ranging from six to eight on 11-point scale (0-10). The skills evaluated the highest by 
the students were collaboration (8), critical thinking (8), and communication (7). The lowest score was given to presentation skills (6). The lowest scores given by individual students to their transversal skills was 4 (by one student for persuasion skills), at the same time 10 points for different skills were used once by seven students (see below Fig. 1).

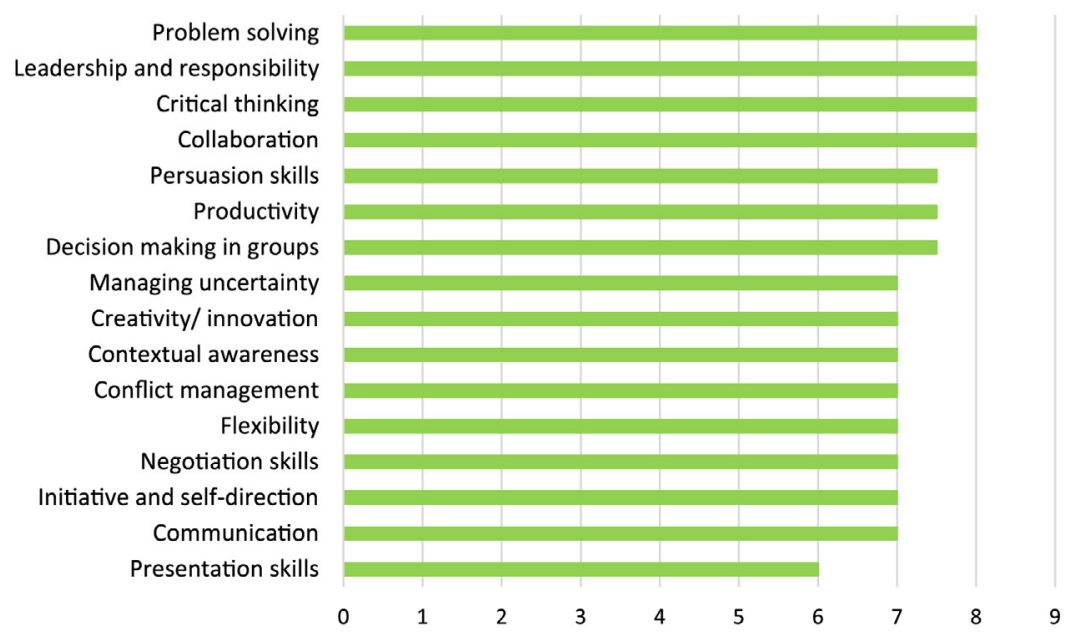

Figure 1. Median evaluation of students of their transversal skill before the simulation (on scale $0-10$ )

Besides rating their transversal skills, the students were asked to choose three skills, which they felt the need to develop the most. Among the transversal skills students would like to develop the most, almost all listed skills were chosen - this shows that students' expectations for the simulation were quite versatile. Two of the most frequently chosen skills were also among the lowest evaluated ones: presentation skills and learning to learn, the third most often chosen skill was productivity. Interestingly, no student marked negotiation skills - perhaps the key competence developed in such simulations (which was mentioned often in the debriefing session).

After the simulation, the students had to fill in another self-evaluation form, where they were asked to reflect if they had a chance to try out and improve each of the 17 transversal skills. Students reported that they were able to use or try out most of the skills, but in such a short time they did not really feel they had improved any of them. Students wrote that learning to learn was one of the skills they could not develop at all because of the nature and duration of the simulation. Surprisingly, they also reported that conflict management could not really be put to use since the groups were finding compromises very fast. This could also be due to the fact that the group of students were rather homogeneous and with similar backgrounds. 
In addition, the students were asked to reflect separately on the three skills they had singled out before the simulation and then choose three skills they now felt they needed to develop further. The most often chosen skills were negotiation skills, as well as conflict management and presentation skills. Again, almost all competencies were chosen - which shows that students get quite different learning experiences out of the same simulation.

\section{Discussion and Conclusions}

In this study, we explored the perceived affordances and limitations of social simulations (Gredler, 2004) as an online learning method to acquaint university students with transversal skills.

The social simulation required the students to work closely in groups, develop strategies and messages, negotiate and find consensus with other groups in order to achieve their goals.

Our study demonstrates that one simulation exercise does not let to improve the transversal skills much, but gives quite a good idea to the students what they are good at and what they need to develop in the future. Looking at the student reflections, we can conclude that the role of simulation is not really to be a teaching tool for transversal skills. Rather it works as a self-testing or reflection tool for the students where they can test out different skills and have new discoveries about themselves: what they are (already) good at and what they could work on further.

Besides that, reflecting about transversal skills does not come easy for students - they tend to over or under-estimate their skills, do not consider them as important (Rarieya, 2005). Simulation is one of the best tools (in the classroom format) to test and analyze actual skills. As pointed out in the theoretical part, Schön (1987) describes the formation of new knowledge as a result of increasing students' self-awareness of one's repertoire of knowledge and skills through creating specific circumstances during the learning. Our testing of simulation indicated that it is a great method that helps to sensitize students about their transversal skills. Therefore, debriefing is a crucial part of the simulation and should direct students to think about the learning experience to raise self-awareness.

Our material suggests that online environments are suitable for conducting social simulations and training specific skills. Online simulations do not hinder application of the same skills as in in-person meetings. It has similar limitations to all online teaching and learning activities that happen in groups: problems with getting noticed, getting heard (fight or fly), and time management. Some specific limitations related to the online environment that we identified in our study were mainly linked to students' inexperience with digital tools, technical limitations of usable digital 
platforms, and psychological barriers related to uncertainty and lack of competencies. Still, learning online the students gain experience to work effectively, discuss and solve problems. In addition, the students reported that participating in the simulation online created a buffer space for them and created a "persona" to act differently than usual, be more open and brave to try out various skills.

However, some transversal skills are even more required online like presentation, negotiations, time management. Due to the COVID-19 pandemic related restrictions, online simulations were a forced option for us, but even after returning to classrooms, teachers should consider using online formats and the opportunity to conduct simulations online.

The study comes with some limitations. Obviously, two examples analyzed in the paper do not give definite answers about transversal skills and online arrangements. There are several challenges with online simulations to be explored further: how to let the students express themselves during group discussions, the role of the facilitator in the group discussions to ensure inclusion also of the more silent/shy ones etc.

\section{Acknowledgements}

The study was supported by the European Union Erasmus + program KA2: Cooperation for innovation and the exchange of good practices, Strategic partnerships for higher education, project "Simulation Games in Strategic Communication” (2018-1-LV01-KA203-046981)

\section{References}

Betts, J. (2004). Theology, therapy or picket line? What's the "good" of reflective practice in management education? Management Education, 5, 239-251. https://doi.org/ $10.1080 / 14623940410001691009$

Buckley, P., \& Doyle, E. (2016). Gamification and student motivation. Interactive Learning Environments, 24(6), 1162-1175. https://doi.org/10.1080/10494820.2014.964263

Chang, B. (2019). Reflection in learning. Online Learning, 23(1), 95-110. 10.24059/olj. v23i1.1447

Coulson, D., \& Harvey, M. (2013). Scaffolding student reflection for experience-based learning: a framework. Teaching in Higher Education, 18(4), 401-413. https://doi.org/ 10.1080/13562517.2012.752726

Cummings, C., Mason, D., Shelton, K., \& Baur, B. (2015). Active Learning Strategies for Online and Blended Learning Environments. In J. Keengwe, \& J. J. Agamba (Eds.), Models for Improving and Optimizing Online and Blended Learning in Higher Education (pp. 58-82). IGI Global. 10.4018/978-1-4666-6280-3

Davidsson, P., \& Verhagen, H. (2017). Types of Simulation. In B. Edmonds, \& R. Mayer (Eds.), Simulating Social Complexity Handbook (pp. 23-37). Springer International Publishing. 10.1007/978-3-540-93813-2 
Deep, S., Salleh, B. M., \& Othman, H. (2019). Study on problem-based learning towards improving soft skills of students in effective communication class. International Journal of Innovation and Learning, 25(1), 17-34. 10.1504/IJIL.2019.096512

Dewey, J. (1910). How We Think: A Restatement of the Relation of Reflective Thinking to the Educative Process. Boston: D. C. Heath. Retrieved from: https://bef632.files. wordpress.com/2015/09/dewey-how-we-think.pdf

Díaz Pareja, E. M., Cámara Estrella, Á. M., Muñoz Galiano, I. M., \& Ortega-Tudela, J. M. (2018). Group work: Prospective teachers' acquisition of transversal competences. Educational Studies, 44(1), 45-56. https://doi.org/10.1080/03055698.2017.1331841

Direito, I., Pereira, A., \& Duarte, A. M. O. (2014). The development of skills in the ICT Sector: Analysis of engineering students' perceptions about transversal skills. International Journal of Engineering Education, 30(6B), 1556-1561. 0949-149X/91 \$3.00+0.00

European Commission (2011). An Agenda for new skills and jobs. Retrieved from: https:// op.europa.eu/en/publication-detail/-/publication/7f39a8c6-068e-434d-a7ce-a9665 bf227f9

Goggin, D., Sheridan, I., Lárusdóttir, F., \& Guðmundsdóttir, G. (2019). Towards the identification and assessment of transversal skills. INTED2019 Proceedings, pp. 25132519. Retrieved from: https://doi.org/10.21125/inted.2019.0686.

Gredler, M. E. (2004). Games and Simulations and their Relationships to Learning. In D. H., Jonassen (Ed.), Handbook of Research on Educational Communications and Technology (pp. 571-581). Lawrence Erlbaum Associates Publishers.

Helyer, R. (2015). Learning through reflection: The critical role of reflection in workbased learning (WBL). Journal of Work-Applied Management, 7(1), 15-27. https://doi.org/ 10.1108/JWAM-10-2015-003

Hill, C., \& Semler, S. (2001). Simulation enhanced learning: Case studies in leadership development. Personnel Decisions International. Retrieved from: https://learningsim. com/wp-content/uploads/2014/12/sim_enhanced_learning.pdf

Kirkwood-Tucker, T. F. (2004). Empowering teachers to create a more peaceful world through global education: Simulating the United Nations. Theory and Research in Social Education, 32(1), 56-74. https://doi.org/10.1080/00933104.2004.10473243

Krpálek, P., Berková, K., Kubišová, A., Krelová, K. K., Frendlovská, D., Spiesová, D. (2021). Formation of professional competences and soft skills of public administration employees for sustainable professional development. Sustainability, 13(10), 5533. https://doi.org/10.3390/su13105533

Martin, F. \& Parker, M. A. (2014). Use of synchronous virtual classrooms: Why, who, and how? MERLOT Journal of Online Learning and Teaching, 10(2), 192-210.

Milakovich, M. E., \& Wise, J. M. (2019). Digital learning: The challenges of borderless education. Cheltenham, Northampton: Edward Elgar Publishing.

National Research Council (2012). Education for Life and Work: Developing Transferable Knowledge and Skills in the $21^{\text {st }}$ Century. Committee on Defining Deeper Learning and $21^{\text {st }}$ Century Skills, J. W. Pellegrino and M. L. Hilton (Eds.). Board on Testing and Assessment and Board on Science Education, Division of Behavioural and Social Sciences and Education. Washington, DC: The National Academies Press.

Quinton, S., \& Smallbone, T. (2010). Feeding forward: Using feedback to promote student reflection and learning - a teaching method. Innovations in Education and Teaching International, 47(1), 125-135. https://doi.org/10.1080/14703290903525911 
Rarieya, J. (2005). Promoting and investigating students' uptake of reflective practice: A Pakistan case. Reflective Practice Journal, 6(2), 285-294. https://doi.org/10.1080/ 14623940500106518

Reuter, J., Ferreira Dias, M., Madaleno, M., Amorim, M., \& Vitória, A. (2020). Game based learning on transversal skills development: An applied state of the art. $12^{\text {th }}$ International Conference on Education and New Learning Technologies, Online Conference, 6-7 July, 2020, 6010-6019. 10.21125/edulearn.2020.1575

Rushton, A. (2005). Formative assessment: A key to deeper learning. Medical Teacher, 27(6), 509-513. 10.1080/01421590500129159

Schön, D. A. (1987). Educating the Reflective Practitioner: Toward a New Design for Teaching and Learning in the Professions. San Francisco: Jossey-Bass.

Thavikulwat, P. (2009). Social choice in a computer-assisted simulation. Simulation \& Gaming: An Interdisciplinary Journal, 40(4), 488-512. https://doi.org/10.1177/ 1046878109335921

Torres, M. F., Sousa, A. J., \& Torres, R. T. (2018). Pedagogical and technological replanning: A successful case study on integration and transversal skills for engineering freshmen. International Journal of Technology and Design Education, 28(2), 573-591. 10.1007/ s10798-017-9399-y

Varela-Candamio, L., Enriquez-Diaz, J., \& Rouco-Couzo, M. (2020). Gamification as a method for vocational training: Evidence for a business course in Spain. In L. Daniela (Ed.) Pedagogies of digital learning in higher education (pp. 145-162). Abingdon, New York: Routledge. https://doi.org/10.4324/9781003019466

Vlachopoulos, D., \& Makri, A. (2017). The effect of games and simulations on higher education: A systematic literature review. International Journal of Educational Technology in Higher Education, 14, 1-33. https://doi.org/10.1186/s41239-017-0062-1

World Economic Forum (2019). Strategies for the New Economy Skills as the Currency of the Labour Market. Centre for the New Economy and Society White Paper. Retrieved from: http://www3.weforum.org/docs/WEF_2019_Strategies_for_the_New_Economy_Skills.pdf

UNESCO (2013). TVETipedia Glossary. Viewed: 12.06.2020. Retrieved from: https:// unevoc.unesco.org/home/TVETipedia + Glossary $/$ filt $=$ all $/$ id $=577$ 